\title{
MANAGEMENT OF IRRIGATION AND NITROGEN FERTILIZERS TO REDUCE AMMONIA VOLATILIZATION
}

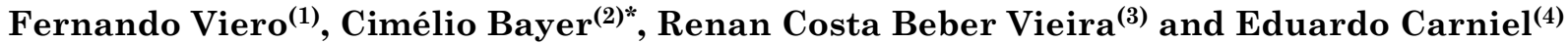 \\ (1) Universidade Federal do Rio Grande do Sul, Departamento de Solos, Programa de Pós-graduação em Ciência do Solo, Porto Alegre, \\ Rio Grande do Sul, Brasil. \\ (2) Universidade Federal do Rio Grande do Sul, Departamento de Solos, Porto Alegre, Rio Grande do Sul, Brasil. \\ (3) Universidade Federal da Fronteira Sul, Cerro Largo, Rio Grande do Sul, Brasil. \\ (4) Universidade Federal do Rio Grande do Sul, Curso de Agronomia, Porto Alegre, Rio Grande do Sul, Brasil. \\ * Corresponding author. \\ E-mail: cimelio.bayer@ufrgs.br
}

\begin{abstract}
Nitrogen losses by ammonia $\left(\mathrm{NH}_{3}\right)$ volatilization can be reduced by appropriate irrigation management or by alternative $\mathrm{N}$ sources, replacing urea. The objective of this study was to evaluate the efficiency of irrigation management and $\mathrm{N}$ source combinations in decreasing $\mathrm{NH}_{3}$ volatilization from an Argissolo Vermelho Distrófico típico cultivated for 28 years with black oat (Avena strigosa) and maize (Zea mays), under no-tillage in the region of Depressão Central, Rio Grande do Sul, Brazil. The experiment was arranged in a randomized block design with split plots with three replications, where the main plots consisted of irrigation systems: no irrigation; irrigation immediately before and irrigation immediately after fertilization. The subplots were treated with different $\mathrm{N}$ sources: urea, urea with urease inhibitor and slow-release fertilizer, at an $\mathrm{N}$ rate of $180 \mathrm{~kg} \mathrm{ha}^{-1}$, broadcast over maize, plus a control treatment without $\mathrm{N}$ fertilization. Ammonia volatilization was assessed using semi-open static collectors for $1,2,4,6$, and 10 days after $\mathrm{N}$ fertilization. In general, more than $90 \%$ of total $\mathrm{NH}_{3}-\mathrm{N}$ losses occurred until three days after $\mathrm{N}$ fertilization, with peaks up to $15.4 \mathrm{~kg} \mathrm{ha}^{-1} \mathrm{~d}^{-1}$. The irrigation was efficient to reduce $\mathrm{NH}_{3}$ losses only when applied after $\mathrm{N}$ fertilization. However, reductions varied according to the $\mathrm{N}$ fertilizer, and were higher for urea $(67 \%)$ and slightly lower for urea with urease inhibitor $(50 \%)$ and slow-release fertilizer (40\%), compared with the mean of the treatments without irrigation and irrigation before fertilization. The use of urea with urease inhibitor instead of urea was only promising under volatilization-favorable conditions (no irrigation or irrigation before $\mathrm{N}$ fertilization). Compared to urea, slow-release fertilizer did not reduce ammonia volatilization in any of the rainfed or irrigated treatments.
\end{abstract}

Keywords: nitrogen sources, $\mathrm{N}$ fertilization, $\mathrm{N}$ losses. 


\title{
RESUMO: MANEJO DA IRRIGAÇÃO E FERTILIZANTES NITROGENADOS PARA REDUZIR A VOLATILIZAÇÃO DE AMÔNIA
}

\begin{abstract}
A redução das perdas de nitrogênio pela volatilização de amônia $\left(\mathrm{NH}_{3}\right)$ pode ser alcançada pelo manejo adequado da irrigação, bem como pelo uso de fontes de Nalternativas à ureia comum. A eficiência desses fatores em reduzir a volatilização de $\mathrm{NH}_{3}$ foi avaliada em experimento conduzido num Argissolo Vermelho Distrófico típico cultivado por 28 anos no sistema aveia-preta/milho (inverno/verão) em plantio direto na Depressão Central do RS. O delineamento experimental foi de blocos casualizados com parcelas subdivididas, em três repetições, onde as parcelas principais receberam os tratamentos de irrigação (sem irrigação e irrigação imediatamente antes ou após a adubação), e nas subparcelas foram aplicadas diferentes fontes de $N$ (ureia comum, ureia com inibidor de urease e fertilizante de liberação lenta) na dose de $180 \mathrm{~kg} \mathrm{ha} \mathrm{k}^{-1} \mathrm{~N}$, além de um tratamento-controle sem adubação nitrogenada. As avaliações de volatilização de $\mathrm{NH}_{3}$ foram realizadas com coletor semiaberto estático aos um, dois, quatro, seis e 10 dias, após a adubação. Mais de $90 \%$ das perdas totais de $\mathrm{NH}_{3}$ por volatilização ocorreram nos três dias que sucederam a aplicação dos fertilizantes, com picos de até 15,4 $\mathrm{kg} \mathrm{ha}^{-1} \mathrm{~d}^{-1}$ de $\mathrm{N}$. A irrigação foi eficiente em reduzir a volatilização de $\mathrm{NH}_{3}$ apenas quando aplicada posterior à adubação. Essa redução variou em razão do fertilizante nitrogenado, sendo superior quando da aplicação da ureia (67 \%) e pouco inferior no caso da ureia com inibidor de urease (50\%) e fertilizante de liberação lenta (40\%), em comparação à média dos tratamentos sem irrigação e com irrigação anterior à adubação. A utilização de ureia com inibidor de urease em substituição à ureia comum apenas evidenciou-se promissora quando em condições propícias à volatilização (sem irrigação ou com irrigação anterior à adubação). Em comparação à ureia comum, o fertilizante de liberação lenta não demonstrou potencial de reduzir volatilização em nenhuma situação avaliada.
\end{abstract}

Palauras-chave: fontes de nitrogênio, adubação nitrogenada, perdas de $N$.

\section{INTRODUCTION}

Urea is the most widely used nitrogen fertilizer for broadcasting on maize in Brazil. However, high $\mathrm{N}$ losses, mainly by ammonia $\left(\mathrm{NH}_{3}\right)$ volatilization, may decrease the fertilization efficiency, limiting maize yields (Fontoura and Bayer, 2010). In general, these losses are highly influenced by environmental conditions in the days following $\mathrm{N}$ application (Duarte et al., 2007; Holcomb et al., 2011). Several alternative management systems were tested with a view to reduce $\mathrm{NH}_{3}$ losses, especially by using alternative $\mathrm{N}$ sources with lower volatilization potential and fertilizer incorporation into the soil (Fontoura and Bayer, 2010). Another promising practice to reduce $\mathrm{NH}_{3}$ volatilization that should be evaluated regionally is the irrigation management.

Volatilization can set in immediately after applying urea to the soil, with solubilization and hydrolysis of the granules (Lara Cabezas et al., 1997b). During hydrolysis, OH ions are released, raising the $\mathrm{pH}$ in surrounding granules, favoring $\mathrm{N}$ conversion to ammonia and consequently, volatilization (Bouwmeester et al., 1985). In this way, $\mathrm{NH}_{3}$ losses are usually highest in the first days after $\mathrm{N}$ fertilization, reaching values between $28-37 \%$ of total losses in the first three days after fertilizer application. However, $\mathrm{N}$ losses by ammonia volatilization depend on the environmental conditions, i.e., they can be lower in dry soil and higher when $\mathrm{N}$ fertilizer is applied to moist soil
(Cantarella et al., 2008), and intensified at high temperatures (Tasca et al., 2011).

In Rio Grande do Sul, the use of irrigation has been expanded, mainly for maize, which is currently cultivated on an acreage of about 80,000 ha under central pivot irrigation (Emater, 2015). Therefore, it is important to evaluate how irrigation managements can mitigate $\mathrm{NH}_{3}$ volatilization losses from $\mathrm{N}$ fertilizers applied to maize. A study conducted in the United States reported a reduction of $90 \%$ of $\mathrm{NH}_{3}$ volatilization by applying $15 \mathrm{~mm}$ irrigation (Holcomb et al., 2011), although no reduction in volatilization was observed in other studies in the southeastern region of Brazil, by applying $28 \mathrm{~mm}$ irrigation after $\mathrm{N}$ fertilization (Lara Cabezas et al., 1997a). With regard to irrigation, an essential aspect is the time of application, whether it is applied before or after fertilization, apart from the applied water volume. The effect of irrigation to minimize $\mathrm{NH}_{3}$ volatilization should be greater if applied after fertilization (Fontoura and Bayer, 2010). The authors found that $\mathrm{NH}_{3}$ volatilization decreased with increasing rain volume in the first five days after fertilization, but was not affected by the rainfall volume in the period before fertilization.

The replacement of urea by alternative $\mathrm{N}$ sources has proved promising in reducing $\mathrm{NH}_{3}$ losses. The addition of urease inhibitor to urea may reduce ammonia volatilization losses by 15 to $78 \%$, according to weather conditions at the time of application (Cantarella et al., 2008; Soares et al., 
2012). Aside from addition of urease inhibitors to urea, the coating of urea granules with polymers is often used to delay $\mathrm{N}$ release from fertilizers, which can decrease $\mathrm{NH}_{3}$ losses by $20 \%$, compared with urea (Pereira et al., 2009). However, a greater effect of these sources to control $\mathrm{NH}_{3}$ losses is possible under volatilization-favorable conditions, but under adequate irrigation management, its effects may be decreased. In this study, both the irrigation management and the potential of $\mathrm{N}$ sources alternative to urea were evaluated for their effect on reducing $\mathrm{NH}_{3}$ loss by volatilization from an Argissolo Vermelho Distrófico típico cultivated for 28 years under no-tillage in the Depressão Central region of RS, Brazil.

\section{MATERIAL AND METHODS}

This study was carried out in the 2010/11 growing season at the Agronomic Experimental Station of the Federal University of Rio Grande do Sul (UFRGS) ( $30^{\circ} 50^{\prime} 52^{\prime \prime} \mathrm{S}$ and $51^{\circ} 38^{\prime} 08^{\prime \prime} \mathrm{W}$ ), Eldorado do Sul, region of Depressão Central, RS, Brazil. The climate is classified as humid subtropical (Cfa), according to the Köppen classification, with annual means of $1,440 \mathrm{~mm}$ rainfall and $19.4{ }^{\circ} \mathrm{C}$ air temperature (Bergamaschi and Melo, 2013). The soil, classified as Argissolo Vermelho Distrófico típico by the Brazilian taxonomy (Typic Paledult by the US taxonomy), contained $220 \mathrm{~g} \mathrm{~kg}^{-1}$ clay (Bayer and Mielniczuk, 1997), and had been cultivated since 1985 with oat (Avena strigosa) in the winter and with maize (Zea mays) in the summer under no-tillage. In the 2010/11 growing season, the $0.00-0.20 \mathrm{~m}$ soil layer had the following properties: organic matter $2.0 \mathrm{dag} \mathrm{kg}^{-1}, \mathrm{pH}$ $\left(\mathrm{H}_{2} \mathrm{O}\right)$ 5.0; pH SMP 6.1; P (Mehlich-1) $47 \mathrm{mg} \mathrm{dm}^{-3}, \mathrm{~K}$ (Mehlich-1) $138 \mathrm{mg} \mathrm{dm}^{-3}, \mathrm{CEC}_{\mathrm{pH}} 7.09 .4 \mathrm{cmol}_{\mathrm{c}} \mathrm{dm}^{-3}$, and base saturation $57 \%$.

The experiment consisted of different $\mathrm{N}$ fertilizers (urea, urea with urease inhibitor and slow-release fertilizer), broadcast on maize at a rate of $180 \mathrm{~kg} \mathrm{ha}^{-1} \mathrm{~N}$, in distinct irrigation management systems (without irrigation, irrigation immediately before and immediately after fertilization), of approximately $10 \mathrm{~mm}$ by sprinkler irrigation. Nitrogen fertilization was applied in the morning to maize in stage V7 (Ritchie et al., 1993). A control treatment without $\mathrm{N}$ fertilization was conducted in all irrigation systems.

For the evaluation of $\mathrm{N}$ losses by ammonia volatilization, semi-open static collectors were used, according to the model described by Nömmik (1973) and modified by Cantarella et al. (2003). Transparent acrylic chambers $(0.40 \mathrm{~m}$ height, $0.15 \mathrm{~m}$ diameter) were fixed to $0.05 \mathrm{~m}$ high PVC bases, partially inserted into the soil, and covered with acrylic lids ( $0.20 \mathrm{~m}$ diameter). To capture ammonia, we used two polyethylene foam discs $\left(28 \mathrm{~g} \mathrm{dm}^{-3}\right.$ density and $0.02 \mathrm{~m}$ height) fixed within the acrylic cylinder, impregnated with $70 \mathrm{~mL}$ phosphoric acid $\left(50 \mathrm{~mL} \mathrm{~L}^{-1}\right)$ and glycerin $\left(40 \mathrm{~mL} \mathrm{~L}^{-1}\right)$ solution. The first foam disc was installed $0.15 \mathrm{~m}$ above ground to capture ammonia volatilized from soil and fertilizers, and the second foam disc was fixed $0.30 \mathrm{~m}$ above ground to intercept the ammonia from the external environment, avoiding contamination of the first foam disc.

The polyethylene foams were replaced at $1,2,4$, 6 and 10 days after $\mathrm{N}$ fertilization, when only the bottom disc foams were exchanged and stored for subsequent $\mathrm{N}$ extraction. To minimize the chamber effect on microclimate (Cantarella et al., 2008), the chambers were always moved to the adjacent PVC base in the same plot when the foams were replaced. This chamber rotation system had the objective to expose all treatments to the same weather conditions (rain, temperature, wind, etc.) in the previous period of collection (Da Ros et al., 2005). In the treatments without irrigation or with irrigation before $\mathrm{N}$ fertilization, the acrylic chambers were installed immediately after fertilization. On the other hand, in the treatment with irrigation after fertilization, the chambers were installed immediately after the end of irrigation. The $\mathrm{N}$ retained in the foams as ammonium phosphate was extracted with $\mathrm{KCl}$ solution $(500 \mathrm{~mL})$, at a concentration of $1.0 \mathrm{~mol} \mathrm{~L}^{-1}$. From this solution volume, a $20 \mathrm{~mL}$ aliquot was subjected to semi-micro Kjeldahl steam distillation (Tedesco et al., 1995).

The amount of volatilized $\mathrm{NH}_{3}-\mathrm{N}$ was calculated based on the total volume of the solution used for washing the disc foams $(500 \mathrm{~mL})$, and the daily volatilization rate was calculated for each $\mathrm{N}$ fertilizer, subtracting $\mathrm{NH}_{3}$ volatilization from the soil without fertilization (control). From these results, the daily volatilization rates $\left(\mathrm{kg} \mathrm{ha}^{-1} \mathrm{~d}^{-1}\right)$ and cumulative losses $\left(\mathrm{kg} \mathrm{ha}^{-1}\right.$ and \% of applied $\mathrm{N})$ were calculated. Meteorological data of the study period (rainfall, air temperature and relative air humidity) were obtained from automatic meteorological station of the UFRGS Department of Forage and Meteorology, about $1 \mathrm{~km}$ away from the experimental area.

The results were subjected to analysis of variance using Proc Mixed (SAS, 2014), considering the irrigation systems and $\mathrm{N}$ fertilizers as fixed and the blocks as random effects. The following statistical model was assumed:

$\mathrm{y}(i j k)=\mu+\mathrm{b} i+\mathrm{N} j+\operatorname{Error} a(i j)+\mathrm{I} k+\mathrm{Nj} \mathrm{I} k+$ Error $b(i j k)$

where $\mu$ is the overall mean; $b$ the blocks $(i=1,2,3)$; $\mathrm{N}$ the $\mathrm{N}$ fertilizers $(j=1,2,3)$; I the irrigation systems $(k=1,2,3)$; and Error the experimental error. The treatment means were estimated by LSMeans and the differences compared by the Tukey test at $5 \%$. 


\section{RESULTS AND DISCUSSION}

\section{Weather conditions}

The mean daily air temperature of the experimental period was $21.4^{\circ} \mathrm{C}$, and the maximum temperature $32.9{ }^{\circ} \mathrm{C}$ (Figure 1a). On the day of fertilization and the following, temperatures higher than $30{ }^{\circ} \mathrm{C}$ were recorded, which can accelerate urea hydrolysis (Holcomb et al., 2011), increasing $\mathrm{N}$ losses by ammonia volatilization. Weather conditions in the period after $\mathrm{N}$ fertilization promoted an environment moderately favorable to $\mathrm{NH}_{3}$ volatilization, resulting in slightly lower daily rates and cumulative amounts than those reported by Viero et al. (2012) for the same region. The occurrence of three rainfall events (1, 3 and 5 days after fertilization), with a total of $25 \mathrm{~mm}$ certainly had a restrictive effect on $\mathrm{NH}_{3}$ losses (Fontoura and Bayer, 2010), in particular the $19 \mathrm{~mm}$ rain on the third day after fertilization.

The relative air humidity exceeded $80 \%$ on most days, favoring dew formation (Figure 1b), which, according to Bouwmeester et al. (1985) can provide favorable conditions for fertilizer solubilization and initiate hydrolysis. This process, associated with wind occurrence can increase $\mathrm{NH}_{3}$ volatilization (Huijsmans et al., 2003), due to water ascent by diffusion in the soil profile, carrying $\mathrm{NH}_{3}$ to the atmosphere. On the other hand, winds and high air temperature can dry the soil surface, reducing gas exchange between soil and atmosphere (Bouwmeester et al., 1985), decreasing $\mathrm{NH}_{3}$ losses.

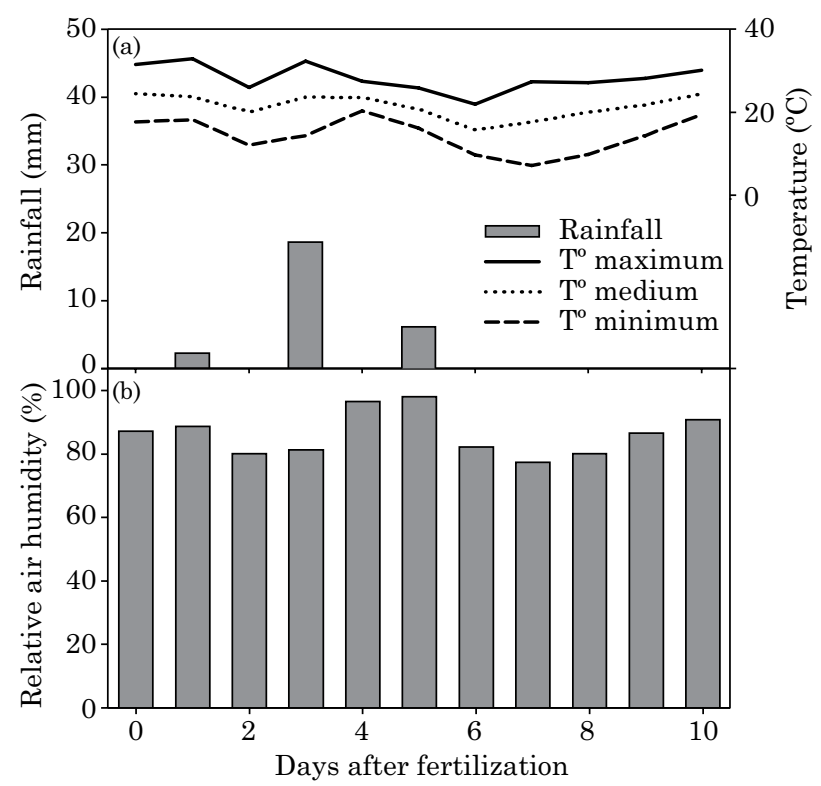

Figure 1. Rainfall; minimum, average and maximum daily air temperature (a); and air relative humidity (b) recorded during the experiment.

\section{Daily volatilization rate}

Daily $\mathrm{NH}_{3}$ loss rates from $\mathrm{N}$ fertilizers were significantly influenced by irrigation management systems and $\mathrm{N}$ sources and varied over time, and highest loss rates were observed up to four days after fertilization (Figure 2).
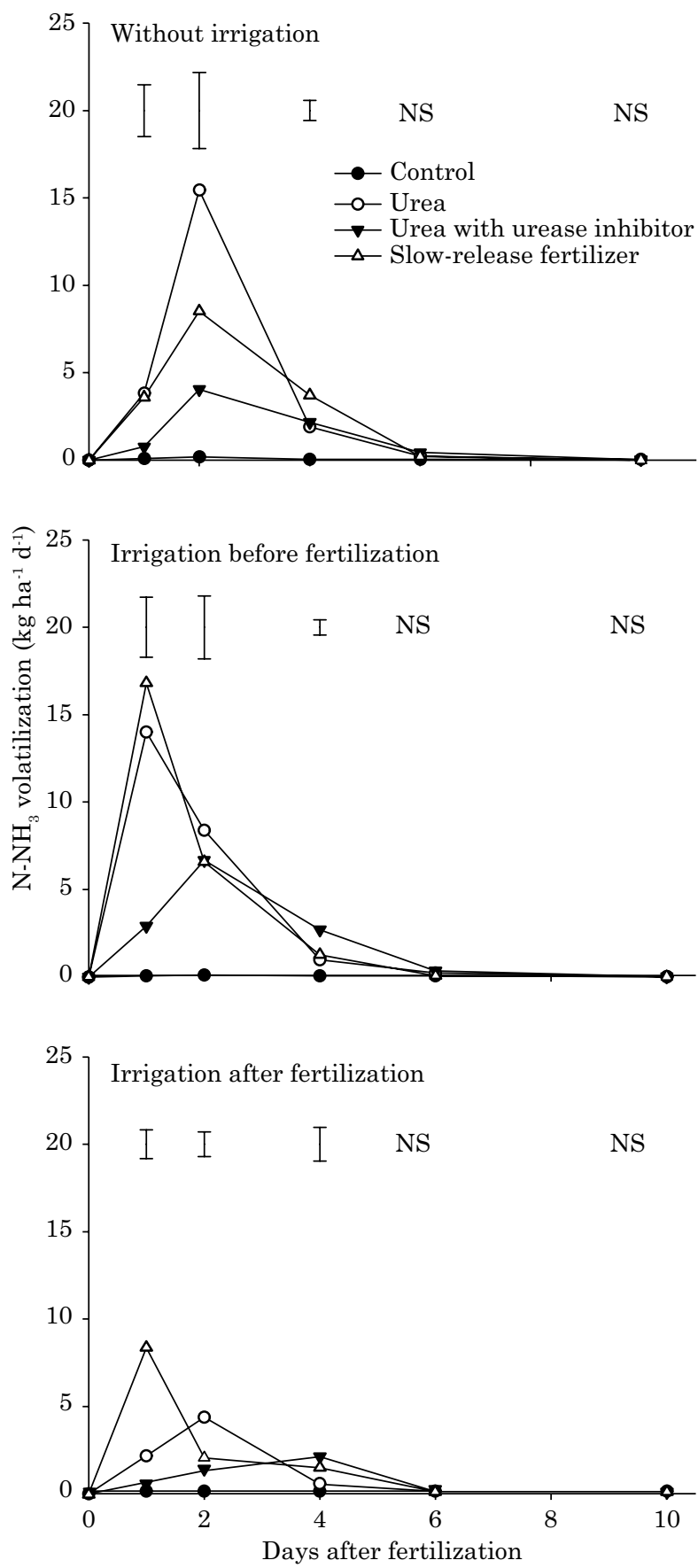

Figure 2. Daily N losses by ammonia volatilization from different $\mathbf{N}$ fertilizers applied without irrigation, irrigation immediately prior to fertilization and fertilization immediately after irrigation. Vertical bars indicate the least significant difference, according to the Tukey test at $5 \%$. NS: not significant. 
After $\mathrm{N}$ fertilization without irrigation, volatilization peaked on the second day after application. In this irrigation system, urea fertilizer had the highest volatilization peak $\left(15.4 \mathrm{~kg} \mathrm{ha}^{-1} \mathrm{~d}^{-1}\right)$, followed by slow-release fertilizer $\left(8.5 \mathrm{~kg} \mathrm{ha}^{-1} \mathrm{~d}^{-1}\right)$ and by urea with urease inhibitor $\left(4.0 \mathrm{~kg} \mathrm{ha}^{-1} \mathrm{~d}^{-1}\right)$ (Figure 2). The substitution of urea by slow-release fertilizer resulted in a $45 \%$ reduction of the volatilization peak, whereas the use of urea with urease inhibitor reduced peak emissions by $75 \%$. This result indicates that the urease inhibitor is more effective in reducing $\mathrm{NH}_{3}$ volatilization than slow-release fertilizer broadcast on maize without irrigation.

However, after the application of $\mathrm{N}$ fertilization after irrigation, in other words to moist soil, mean volatilization peaks of $15 \mathrm{~kg} \mathrm{ha}^{-1} \mathrm{~d}^{-1}$ were observed on the first day after fertilization when using urea and slow-release fertilizer (Figure 2). The performance of urea with urease inhibitor was the same when applied without irrigation, with greater $\mathrm{NH}_{3}$ losses recorded on the second day after fertilization (Figure 2). With the application of fertilizers to moist soil, slow-release fertilizer reached the highest volatilization peak, followed by urea and urea with urease inhibitor. In this irrigation system, only the replacement of urea by urea with urease inhibitor was enough to effectively reduce the daily $\mathrm{NH}_{3}$ loss rates. The high soil moisture resulting from irrigation, which coincided with high temperatures may have contributed to fertilizer dissolution, favoring $\mathrm{N}$ volatilization (Clay et al., 1990; Rojas et al., 2012), since the highest peaks were observed one day after fertilization.

On the other hand, daily volatilization peaks were reduced in all $\mathrm{N}$ fertilizers, when irrigation was applied immediately after $\mathrm{N}$ fertilization, compared to the treatments without irrigation and irrigation before fertilization. The highest volatilization peak was observed from slow-release fertilizer, one day after fertilization, followed by urea, 2 days after fertilization, and urea with urease inhibitor, 4 days after fertilization (Figure 2). The application of $10 \mathrm{~mm}$ water by sprinkler irrigation was effective to reduce the daily $\mathrm{NH}_{3}$ loss rates from all $\mathrm{N}$ fertilizers, as a result of fertilizer incorporation into the soil, facilitating $\mathrm{NH}_{4}^{+}$adsorption to negatively charged soil particles (Holcomb et al., 2011; Viero et al., 2012) and the dissolution of oxidril concentration around fertilizer granules (Da Ros et al., 2005).

Some field studies have shown that $\mathrm{NH}_{3}$ losses by volatilization, especially from urea, are highest until the third day after fertilization (Da Ros et al., 2005; Fontoura and Bayer, 2010; Rojas et al., 2012). Thus, in our study, the rain occurrence on the third day $(19 \mathrm{~mm})$ after $\mathrm{N}$ fertilization possibly prevented higher losses by $\mathrm{NH}_{3}$ volatilization from the treatments without irrigation and irrigation before fertilization. In this sense, we stress that, despite the rainfall of $19 \mathrm{~mm}$ on the third day after fertilization, the effect of irrigation in reducing $\mathrm{NH}_{3}$ losses by volatilization was significant compared to the treatments without irrigation or irrigation before fertilization. However, the absence of rain on the third day would possibly have increased $\mathrm{NH}_{3}$ losses from fertilizers, and irrigation effects would be greater than observed in this study.

\section{Cumulative ammonia volatilization losses}

The daily flux of $\mathrm{NH}_{3}$ losses from $\mathrm{N}$ fertilizers under different irrigation management systems resulted in distinct cumulative $\mathrm{N}$ losses over the evaluation period (Table 1). In the non-irrigated management, urea was the $\mathrm{N}$ source with highest cumulative $\mathrm{NH}_{3}$ loss, approximately $13 \%$ of applied N (Figure 3), but did not differ statistically from slow-release fertilizer, indicating that this fertilizer was not as effective in reducing $\mathrm{NH}_{3}$ losses (Table 1). However, these $\mathrm{NH}_{3}$ losses from urea were lower than losses reported in non-irrigated field experiments in the Depressão Central region, with losses close to $25 \%$ of applied N (Viero et al., 2012), but similar to losses reported by Da Ros et al. (2005), of $15 \%$ of applied N.

The addition of urease inhibitor to urea was effective in reducing the cumulative $\mathrm{NH}_{3}-\mathrm{N}$ losses by volatilization without irrigation, representing a decrease of $57 \%$ compared to urea (Table 1). The efficiency of urease inhibitor was mentioned in a number of studies, ranging from 15 to $78 \%$, according to the environmental conditions (Cantarella et al., 2008; Pereira et al., 2009; Viero et al., 2014). Therefore, where

Table 1. Cumulative $\mathrm{N}$ loss by ammonia volatilization from different nitrogen fertilizers broadcast on maize in different irrigation systems

\begin{tabular}{lccc}
\hline Treatment & Without irrigation & Irrigation before fertilization & Irrigation after fertilization \\
\hline & & $\mathrm{kg} \mathrm{ha}{ }^{-1} \mathrm{~N}$ & $7.9 \mathrm{Bb}$ \\
Urea & $23.5 \mathrm{Aa}$ & $24.9 \mathrm{Aa}$ & $6.5 \mathrm{Bb}$ \\
Urea with urease inhibitor & $10.1 \mathrm{Bb}$ & $15.8 \mathrm{Ab}$ & $13.6 \mathrm{Ba}$ \\
Slow-release fertilizer & $19.9 \mathrm{ABa}$ & $26.1 \mathrm{Aa}$ & \\
CV (\%) & & 12.7 & \\
\hline
\end{tabular}

Means followed by the same letter do not differ statistically by the Tukey test at $5 \%$. Capital letters compare irrigation systems for the same $\mathrm{N}$ fertilizer and lowercase letters compare fertilizers within the same irrigation system. CV: coefficient of variation. 


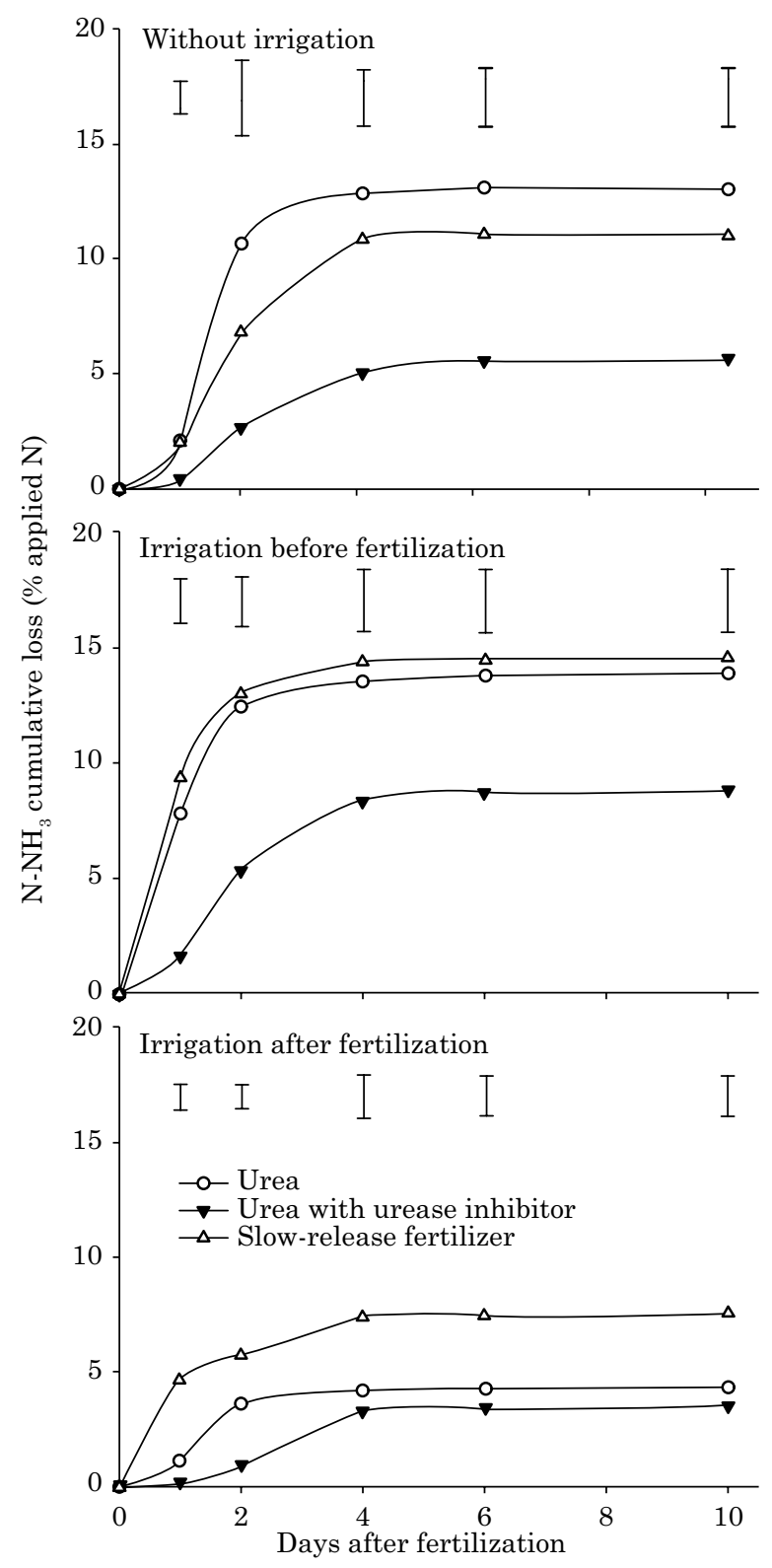

Figure 3. Cumulative $N$ loss by ammonia volatilization from different $N$ fertilizers broadcast on maize without irrigation, with irrigation before fertilization and irrigation after fertilization. Vertical bars indicate least significant difference by the Tukey test at $5 \%$.

irrigation is unavailable, the application of urea with urease inhibitor may be indicated to reduce $\mathrm{NH}_{3}$ losses.

Under irrigation prior to fertilization, the largest cumulative $\mathrm{NH}_{3}$ loss (approximately $14.5 \%$ of applied $\mathrm{N})$ was observed in the treatment with the application of slow-release fertilizer (Figure 3), although the treatment mean did not differ significantly from urea. In this irrigation system, $\mathrm{NH}_{3}$ losses from urea with urease inhibitor were approximately $37 \%$ lower than from slow-release fertilizer and urea (Table 1).

In the irrigation management where irrigation was applied immediately after fertilization, it was observed that the $\mathrm{NH}_{3}$ loss was greatest from slow-release fertilizer, whereas the cumulative loss was approximately $7.5 \%$ of applied N (Figure 3 ). Nitrogen losses from urea and urea with inhibitors were similar, around $4.0 \%$ of applied N. These results suggest that, under irrigation, urea must not necessarily be replaced by other $\mathrm{N}$ fertilizers, in view of the low cumulative $\mathrm{NH}_{3}$ losses from all $\mathrm{N}$ fertilizers. The lower $\mathrm{NH}_{3}$ volatilization in this irrigation system may be due to the lateral and vertical movement of fertilizer-derived ammonium (Dawar et al., 2011), promoted by the addition of water, from the surface into the subsurface soil layer, where it can persist, adsorbed to negatively charged soil particles.

The magnitude of $\mathrm{N}$ volatilization losses was influenced by the irrigation systems (Table 1), in which the $\mathrm{NH}_{3}$ losses from urea applied before irrigation were significantly lower compared to the same treatment without irrigation and with fertilization immediately after irrigation (Table 1), representing a reduction of approximately $65 \%$ of $\mathrm{NH}_{3}$ losses. Ammonia volatilization from urea with urease inhibitor was also lowest in the treatment with irrigation after fertilization, reducing losses by $60 \% \mathrm{NH}_{3}$ compared to fertilization preceding irrigation. The effect of fertilizer incorporation by irrigation was also observed with the application of slow-release fertilizer, where $\mathrm{NH}_{3}$ losses dropped by $50 \%$ compared to fertilization after irrigation (Table 1). Regardless of the irrigation system, over $90 \%$ of $\mathrm{NH}_{3}$ losses from urea occurred up to three days after fertilization. These results are similar to those of Duarte et al. (2007) and Rojas et al. (2012), who reported higher ammonia volatilization between the second and third day after $\mathrm{N}$ fertilization, applied to soil at different moisture contents.

\section{CONCLUSIONS}

Sprinkler irrigation immediately after $\mathrm{N}$ fertilization is effective in reducing ammonia losses by volatilization, particularly from urea. The same behavior of reduced losses should be observed when urea is followed by rainfall immediately after urea application.

The addition of urease inhibitor to urea is also effective in reducing ammonia volatilization, independent of irrigation. However, the replacement of urea by slow-release fertilizer is not an effective alternative to mitigate ammonia losses.

Irrigation immediately after $\mathrm{N}$ fertilization reduces ammonia losses from urea, while irrigation (or rainfall) before $\mathrm{N}$ fertilization can increase ammonia volatilization. 


\section{REFERENCES}

Bayer C, Mielniczuk J. Características químicas do solo afetadas por métodos de preparo e sistemas de cultura. R Bras Ci Solo. 1997;21:105-12.

Bergamaschi H, Melo RW. Boletim agrometeorológico da estação experimental agronômica da UFRGS: 1970-2012. Porto Alegre: Universidade Federal do Rio Grande do Sul; 2013.

Bouwmeester RJB, Vlek PLG, Stumpe JM. Effect of environmental factors on ammonia volatilization from a urea-fertilized soil. Soil Sci Soc Am J. 1985;49:376-81.

Cantarella H, Mattos D, Quaggio JA, Rigolin AT. Fruit yield of Valencia sweet orange fertilized with different $\mathrm{N}$ sources and the loss of applied N. Nutr Cycl Agroecosyst. 2003;67:215-23.

Cantarella H, Trivelin PCO, Contin TLM, Dias FLF, Rossetto R, Marcelino R, Coimbra RB, Quaggio JA. Ammonia volatilization from urease inhibitor-treated urea applied to sugarcane trash blankets. Sci Agric. 2008;65:397-401.

Clay DE, Malzer GL, Anderson JL. Ammonia volatilization from urea as influenced by soil temperature, soil water content, and nitrification and hydrolysis inhibitors. Soil Sci Soc Am J. 1990;54:263-66.

Da Ros CO, Aita C, Giacomini SJ. Volatilização de amônia com aplicação de ureia na superfície do solo, no sistema plantio direto. Ci Rural. 2005;35:799-805.

Dawar K, Zaman M, Rowarth J, Blennerhassett J, Turnbull M. Urea hydrolysis and lateral and vertical movement in the soil: effects of urease inhibitor and irrigation. Biol Fertil Soils. 2011;47:139-46.

Duarte FM, Pocojeski E, Silva LS, Graupe FA, Britzke D. Perdas de nitrogênio por volatilização de amônia com aplicação de ureia em solo de várzea com diferentes níveis de umidade. Ci Rural. 2007;37:705-11.

Empresa de Assistência Técnica e Extensão Rural do Estado de Minas Gerais - Emater. Área técnica: Apoio a gestão e produção - irrigação. 2015. [Accessed: Apr 7, 2015]. Available: http://www.emater.tche.br/ site/area-tecnica/apoio-a-gestao-e-producao/irrigacao.php.

Fontoura SMV, Bayer C. Ammonia volatilization in no-till system in the south-central region of the State of Paraná, Brazil. R Bras Ci Solo. 2010;34:1677-84.

Holcomb JC, Sullivan DM, Horneck DA, Clough GH. Effect of irrigation rate on ammonia volatilization. Soil Sci Soc Am J. 2011;75:2341-47.
Huijsmans JFM, Hol JMG, Vermeulen GD. Effect of application method, manure characteristics, weather and field conditions on ammonia volatilization from manure applied to arable land. Atmos Environ. 2003;37:3669-80.

Lara Cabezas WAR, Korndörfer GH, Motta SA. Volatilização de $\mathrm{N}-\mathrm{NH}_{3}$ na cultura de milho: I. Efeito da irrigação e substituição parcial da ureia por sulfato de amônio. R Bras Ci Solo. 1997a;21:481-7.

Lara Cabezas WAR, Korndörfer GH, Motta SA. Volatilização de N-NH${ }_{3}$ na cultura de milho: II. Avaliação de fontes sólidas e fluídas em sistema de plantio direto e convencional. R Bras Ci Solo. 1997b;21:489-96.

Nömmik $\mathrm{H}$. The effect of pellet size on the ammonia loss from urea applied to forest soil. Plant Soil. 1973;39:309-18.

Pereira HS, Leão AF, Verginassi A, Carneiro MAC. Ammonia volatilization of urea in the out-of-season corn. R Bras Ci Solo. 2009;33:1685-94.

Ritchie SW, Hanway JJ, Benson GO. How a corn plant develops. Ames: Iowa State University; 1993.

Rojas CAL, Bayer C, Fontoura SMV, Weber MA, Viero F. Volatilização de amônia da ureia alterada por sistemas de preparo de solo e plantas de cobertura invernais no Centro-Sul do Paraná. R Bras Ci Solo. 2012;36:261-70.

Statistics Analyses System Institute - SAS. Procedures. 2014 [Accessed May 2014]. Available at: http://support.sas.com/index.html.

Soares JR, Cantarella H, Menegale MLC. Ammonia volatilization losses from surface-applied urea with urease and nitrification inhibitors. Soil Biol Biochem. 2012;52:82-9.

Tasca FA, Ernani PR, Rogeri DA, Gatiboni LC, Cassol PC. Volatilização de amônia do solo após a aplicação de ureia convencional ou com inibidor de urease. R Bras Ci Solo. 2011;35:493-502.

Tedesco MJ, Gianello C, Bissani CA, Bohnen H, Volkweiss SJ. Análise de solo, plantas e outros materiais. Porto Alegre: Universidade Federal do Rio Grande do Sul; 1995.

Viero F, Bayer C, Fontoura SMV, Moraes RP. Ammonia volatilization from nitrogen fertilizers in no-till wheat and maize in Southern Brazil. R Bras Ci Solo. 2014;38:1515-25.

Viero F, Correia SL, Menegati GB, Silva PRF, Bayer C, Carniel E. Redução de perdas de nitrogênio por volatilização pelo uso de inibidor de urease e manejo da irrigação em milho. Inf Agron. 2012;139:18-20. 